Article

\title{
Hydroconversion of Waste Cooking Oil into Green Biofuel over Hierarchical USY-Supported NiMo Catalyst: A Comparative Study of Desilication and Dealumination
}

\author{
Zongwei Zhang ${ }^{1,2} \mathbb{B}^{(D)}$, Qingfa Wang ${ }^{1, *} \mathbb{( D}$, Hao Chen ${ }^{1}$ and Xiangwen Zhang ${ }^{1, *}$ \\ 1 Key Laboratory of Green Chemical Technology of Ministry of Education, School of Chemical Engineering \\ and Technology, Tianjin University, Tianjin 300072, China; zhv116@163.com (Z.Z.); \\ chen26352857@126.com (H.C.) \\ 2 Airport Department, Civil Aviation University of China, Tianjin 300300, China \\ * Correspondence: qfwang@tju.edu.cn (Q.W.); zhangxiangwen@tju.edu.cn (X.Z.); \\ Tel./Fax: +86-22-2789-2340 (Q.W. \& X.Z.)
}

Received: 1 September 2017; Accepted: 19 September 2017; Published: 22 September 2017

\begin{abstract}
The hydroconversion of waste cooking oil into hydrocarbon fuel was investigated over the hierarchical USY zeolite-supported NiMo catalysts which were prepared by dealumination $\left(\left(\mathrm{NH}_{4}\right)_{2} \mathrm{SiF}_{6}\right) /$ desilication $(\mathrm{NaOH})$. The physical and acidity properties of the hierarchical catalysts were characterized by X-ray diffraction (XRD), the Brunauer-Emmett-Teller (BET) infrared spectroscopy of adsorbed pyridine (Py-IR), ammonia temperature-programmed desorption $\left(\mathrm{NH}_{3}-\mathrm{TPD}\right)$, and $\mathrm{H}_{2}$ temperature-programmed reduction $\left(\mathrm{H}_{2}-\mathrm{TPR}\right)$. The Brønsted/Lewis (B/L) acid distribution was little affected by dealumination and the acid density decreased significantly. However, the highly-desilicated catalysts decreased the $\mathrm{B} / \mathrm{L}$ ratio obviously. Therefore, many more Mo species in the $\mathrm{NiMoO}_{4}{ }^{-}$and $\mathrm{MoO}_{3}$ phases were produced in the AHFS-treated catalysts, while more high-valence-state Mo species in the $\mathrm{NiMoO}_{4}{ }^{-}$phase were formed in the $\mathrm{NaOH}$-treated catalysts. The AHFS-treated catalysts showed higher catalytic activity and better $\mathrm{DCO}_{2}$ selectivity and selective cracking for jet fuel. The $42.3 \%$ selectivity of jet fuel and $13.5 \%$ selectivity of jet-range aromatics was achieved over the $8 \mathrm{wt} \%\left(\mathrm{NH}_{4}\right)_{2} \mathrm{SiF}_{6}$-treated catalyst with $67 \% \mathrm{DCO}_{2}$ selectivity.
\end{abstract}

Keywords: waste cooking oil; hydroconversion; bio-jet fuel; dealumination; desilication

\section{Introduction}

The development of renewable fuels resources has received great attention because of the global environmental concern and the exhaustion of the fossil fuel resources [1-3]. The high demand of jet fuel has made the research of bio-jet fuel significant because of the rapid development in the aircraft industry and the compulsory reduction of carbon emissions. Hydroconversion of vegetable oils to obtain bio-jet fuel was a potential processing route [4-9]. Several routes based on hydrotreating of vegetable oil have been performed to produce aviation biofuels from biomass feedstocks. Among these routes, two-step processes are industrially available. Hydrodeoxygenation (HDO) is firstly employed to produce long-chain paraffins, followed by a hydroisomerization-hydrocracking to improve the cold properties and to obtain the desired chain length in another reactor. For example, the UOP Renewable Jet Fuel Process $^{\mathrm{TM}}$, the Nesto Oil NEXBTL process, and Haldor Topsoe's HydroFlex ${ }^{\mathrm{TM}}$ technology have been developed to convert vegetable oil (jatropha oil, palm oil, etc.) into green jet fuel based on commercial Ni-based catalysts [10,11]. Recently, many works have been conducted to develop a one-step process to prepare bio-jet fuel from lipids. In these cases, HDO and hydroisomerization-hydrocracking occurred in a reactor. Sinha and co-workers [12] investigated the bio-jet fuel production from jatropha oil 
by a single-step route using hierarchical ZSM-5-supported NiMo or NiW catalysts. A high yield of jet-ranged $\left(C_{9}-C_{15}\right)$ hydrocarbons with excellent isomerization selectivity was obtained $(40-45 \%$ with $i / n=2-6$ and $40-50 \%$ with $i / n=3-13$ over NiW and NiMo catalysts, respectively). The product distribution (jet fuel with desired aromatics, diesel, and gasoline) was tailored by the sulphided NiMo and NiW catalysts supported on hierarchical mesoporous SAPO-11 [13].

Generally, waste cooking oil is $2-3$ times cheaper than vegetable oils $[14,15]$ and has become a promising feedstock in biodiesel production [16-18]. However, very few works have been performed producing renewable jet fuel from WCO. Cheng's group [19] investigated three types of zeolites (Meso-Y, SAPO-34, and HY) loaded with nickel to convert waste cooking oil into bio-jet fuel. Zeolite Meso- $Y$ exhibited a high yield of $\mathrm{C}_{8}-\mathrm{C}_{16}$ alkane and a low aromatic yield from waste cooking oil. Hence, the research for new approaches to produce jet fuel from WCO is significant for academic research and potential industrial application.

Hierarchical zeolite showed excellent activity for the hydroconversion of lipids to hydrocarbons $[12,13,19,20]$. Recently, dealumination [21-23] and/or desilication [24-26] has been used as a versatile method to prepare the hierarchical zeolite. Many works have been done to regulate the pore structure and the surface acidity by these methods [22-26]. Although some work has compared the catalytic performance of desilicated and dealuminated zeolites in hydrodeoxygenation of vegetable oils. However, the nature of these methods on their catalytic activity is rarely involved. Moreover, owing to the significant relevance of zeolite $Y$ to industrial catalysis, USY zeolite has been widely used as an acid catalyst in fluid catalytic cracking and hydrocracking because of its strong acidity and high hydrothermal stability [27]. However, despite the supremacy of $Y$ zeolites in petroleum refining, diffusion limitations were recognized as a major problem that needed to be resolved to unleash its full potential. Therefore, in this work, the dealumination and desilication of the USY zeolite were investigated by $\left(\mathrm{NH}_{4}\right)_{2} \mathrm{SiF}_{6}$ (AHFS) and $\mathrm{NaOH}$ leaching, respectively. The catalytic activity of these modified zeolites was evaluated by converting WCO into biofuel. The object is to understand the role of desilication and dealumination on tuning the properties of the pore structure and the acidity distribution for its catalytic hydrodeoxygenation of WCO and, furthermore, to provide some sights for rational design of new hierarchical zeolite in WCO conversion.

\section{Results and Discussion}

\subsection{Textural Structures of Desilicated and Dealuminated USY Zeolites}

Table 1 shows the structure variation of modified USY zeolite by desilication and dealumination. The unit cell size of AHFS-dealuminated USY (AHFS-Y) gradually decreased with the acid treatment due to the removal of the longer $\mathrm{Al}-\mathrm{O}$ band in the zeolite. Consequently, the $\mathrm{Si} / \mathrm{Al}$ ratio increased. However, after desilication, the unit cell size of $\mathrm{NaOH}$-treated USY increased and the $\mathrm{Si} / \mathrm{Al}$ ratio decreased due to the removal of silicon. Obviously, the relative crystallinity of dealuminated and desilicated USY decreased dramatically. Moreover, the dealuminated catalysts of 4AHFS-Y and 8AHFS-Y showed similar relative crystallinity with the desilicated catalysts of $1 \mathrm{NH}-\mathrm{Y}$ and $4 \mathrm{NH}-\mathrm{Y}$, respectively. Thus, these catalysts were further investigated. As for the parent USY and desilicated USY zeolites, the framework silicon-to-aluminum ratios determined by $\mathrm{X}$-ray diffraction (XRD) ( $\left.\mathrm{Si} / \mathrm{Al}_{\mathrm{XRD}}\right)$ was lower than the bulk silicon-to-aluminum ratio determined by $X R F$, indicating the presence of a large amount of extra-framework silicon [22,25]. This suggests that the extra-framework silicon was easier to remove or part of exfoliated silicon recrystallized in the alkali-treatment $[22,25,26]$.

After AHFS-dealumination, the framework Si/Al ratio significantly increased with a slight increase of bulk Si / Al ratio, and it was obviously beyond the bulk Si/Al ratio for the samples treated with high AHFS concentration (8AHFS-Y and 12AHFS-Y). This strongly suggested that the framework aluminum was mainly removed and the majority of extracted framework aluminum (FAL) turned into extra-framework aluminium (EFAL) in the AHFS treatment $[28,29]$. This was because the HF 
acid produced from excessive AHFS destroyed the framework of USY and the vacancies created by dealumination increased $[30,31]$.

Table 1. Crystal structure parameters of modified USY.

\begin{tabular}{ccccc}
\hline Sample & $\mathbf{a}_{\mathbf{o}}(\mathbf{A})$ & $\mathbf{S i} / \mathbf{A l}_{\mathbf{X R D}}$ & $\mathbf{S i} / \mathbf{A l}_{\mathbf{X R F}}$ & Relative Crystallinity (\%) \\
\hline USY & 24.515 & 4.1 & 8.8 & 100 \\
4AHFS-Y & 24.394 & 7.2 & 8.9 & 49 \\
8AHFS-Y & 24.247 & 28.8 & 10.2 & 37 \\
12AHFS-Y & 24.246 & 29.3 & 12.3 & 17 \\
1NH-Y & 24.485 & 4.7 & 6.6 & 50 \\
4NH-Y & 24.547 & 3.7 & 4.9 & 31 \\
\hline
\end{tabular}

\subsection{Acidity Distribution of Desilicated and Dealuminated USY}

The acidity properties of samples were investigated by Py-FTIR and $\mathrm{NH}_{3}$-TPD. From Figure 1 , it could be observed that two $\mathrm{NH}_{3}$ desorption peaks were detected in the range of $150-300{ }^{\circ} \mathrm{C}$ and $300-550{ }^{\circ} \mathrm{C}$, which were assigned to weak and strong acidity, respectively. These peaks were deconvoluted (see Figure S1) and the acidity distribution calculated according to the amount of desorbed $\mathrm{NH}_{3}$ was summarized in Table 2. The USY zeolite showed a high B/L ratio (2.92), indicating that USY was dominated by Brønsted acidity. The amounts of Brønsted acid and Lewis acid sites decreased with the increase of AHFS concentration due to the removal of framework $\mathrm{Al}$, the Brønsted acid site. However, the AHFS-treated catalysts showed the similar B/L ratio indicating that dealumination had little influence on the distribution of Brønsted and Lewis site. The amount of strong acid sites increased under mild AHFS treatment $(4 \mathrm{wt} \%)$ because of the superacidity of amorphous $\mathrm{SiO}_{2}-\mathrm{Al}_{2} \mathrm{O}_{3}$ or EFAl formed after dealumination [21,28].

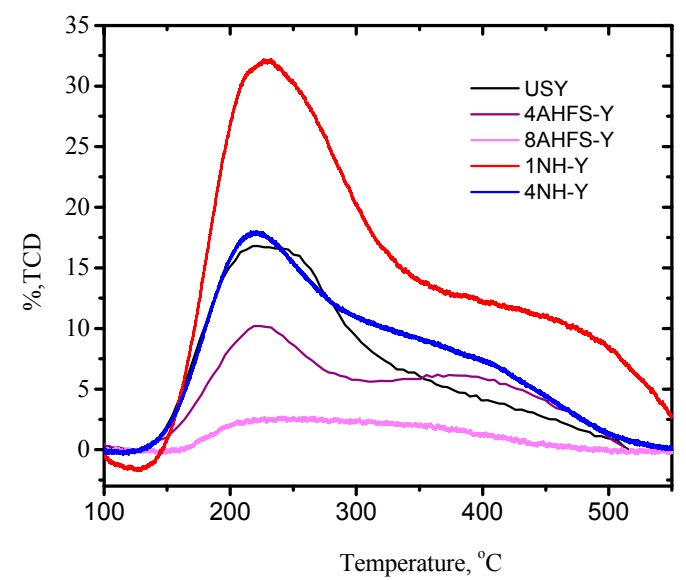

Figure 1. $\mathrm{NH}_{3}$-TPD profiles of AHFS- and alkaline-treated USY.

Table 2. Acidity properties of samples $(\mu \mathrm{mol} / \mathrm{g})$.

\begin{tabular}{cccccc}
\hline Sample & B & L & Weak Acidity & Strong Acidity & B/L \\
\hline USY & 1851 & 634 & 626 & 660 & 2.92 \\
4AHFS-Y & 1440 & 483 & 402 & 857 & 2.98 \\
8AHFS-Y & 160 & 55 & 66 & 230 & 2.91 \\
1NH-Y & 2374 & 602 & 1545 & 1518 & 3.94 \\
4NH-Y & 1604 & 1254 & 658 & 1130 & 1.28 \\
\hline
\end{tabular}

The weak acidity and strong acidity of alkali-treated USY were much larger than the parent one due to the increase of $\mathrm{Al}$ content in the zeolites. The amount of Brønsted acidity of $1 \mathrm{NH}-\mathrm{Y}$ sample 
significantly increased, probably due to the reinsertion of aluminum species to vacancies by silicon removal [22]. The 4NH-Y sample showed higher Lewis acid sites density because of the large part of FAL transform into EFAL. Therefore, the $1 \mathrm{NH}-\mathrm{Y}$ sample showed a high B/L ratio (3.94), but a lower $\mathrm{B} / \mathrm{L}$ ratio (1.28) for the $4 \mathrm{NH}-\mathrm{Y}$ sample.

\subsection{Pore Size Distribution of Treated USY Zeolites}

The $\mathrm{N}_{2}$ adsorption-desorption isotherms and pore size distributions using the NLDFT (non-local density functional theory) model are illustrated in Figure 2. The porous properties and the hierarchy factor (HF) values of all the catalysts are summarized in Table 3. The mesopore volume and the HF value increased considerably as the concentration of AHFS or $\mathrm{NaOH}$ increased, indicating that the introduction of mesopore reduced the micropore volume. From the pore size distribution profiles the peaks of AHFS treated samples shifted to the right and the intensities strengthened, indicating that the size and the amount of the mesopores increased. This indicates that the formation of secondary mesopores was closely related to the dealumination method and the mechanism of filling aluminium vacancies by silicon. The silicon insertion rate was too slow to repair the vacancies left by aluminum removal and mesopores formed, and the integrity of the zeolite framework may not be preserved [26]. Thus, with the increase of the mesopores' volume, the crystallinity declined (Table 1). The formation of the mesopores on the subsurface of the dealuminated USY also reduced the surface acidity (Tables 2 and 3) [26]. Moreover, the catalysts treated by $8 \%$ AHFS and $4 \% \mathrm{NaOH}$ showed the comparable HF values. Much higher concentration of AHFS (12\%) would damage part of the formed mesopore leading to the decrease of HF value. As shown in Figure 2, the dealuminated catalysts by highly-concentrated AHFS ( $8 \%$ and $12 \%$ ) showed a high content of mesopores. However, the desilicated catalysts produced much bigger mesopore size than dealuminated catalysts (20-30 nm vs. $12-15 \mathrm{~nm}$ ).

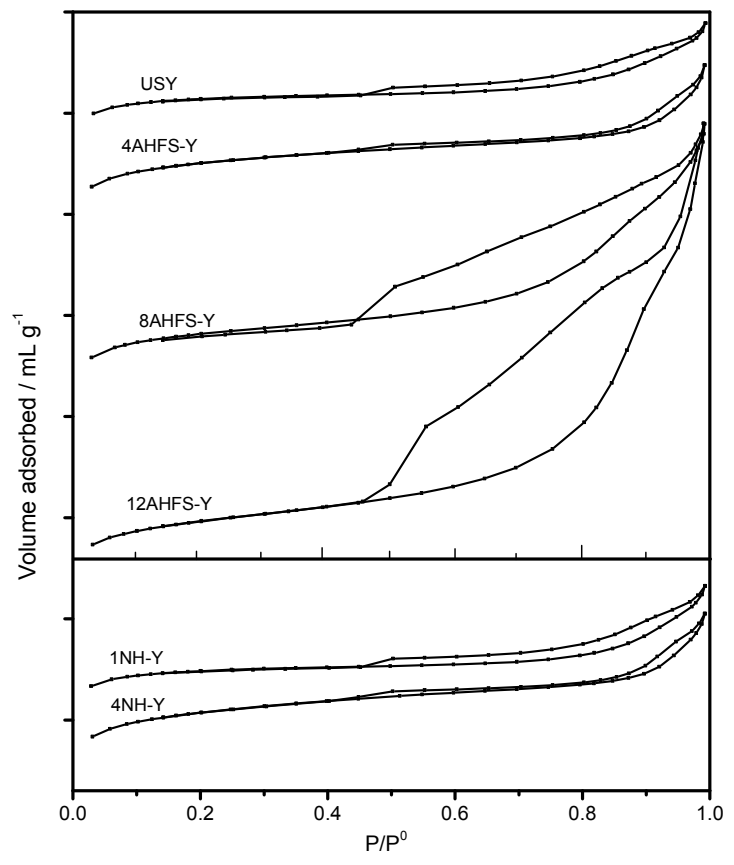

(a)

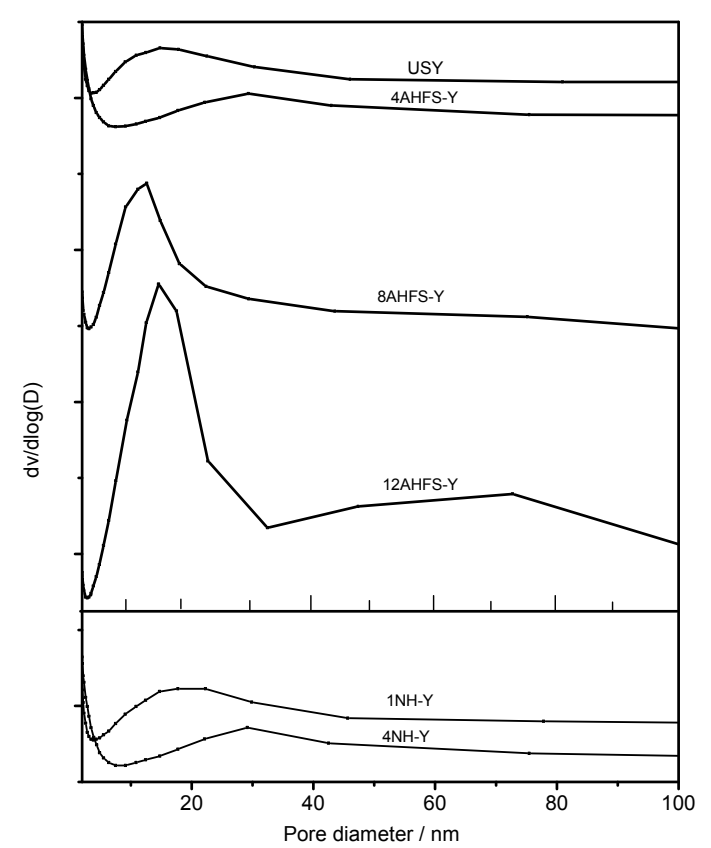

(b)

Figure 2. (a) $\mathrm{N}_{2}$ adsorption-desorption isotherms and (b) the mesopore size distribution for the AHFS-treated and alkaline-treated USY. 
Table 3. The surface area and pore volume data of all the Y-type zeolites.

\begin{tabular}{cccccc}
\hline \multirow{2}{*}{ Samples } & $\mathbf{S}_{\text {micro }}{ }^{\mathbf{a}}$ & $\mathbf{S}_{\mathbf{e x t}} \mathbf{b}$ & $\mathbf{V}_{\text {micro }}{ }^{\mathbf{c}}$ & $\mathbf{V}_{\text {meso }}{ }^{\mathbf{d}}$ & \multirow{2}{*}{$\mathbf{H F} \mathbf{~}$} \\
\cline { 2 - 5 } & $\mathbf{m}^{\mathbf{2}} / \mathbf{g}$ & $\mathbf{m}^{\mathbf{2}} / \mathbf{g}$ & $\mathbf{c m}^{\mathbf{3}} / \mathbf{g}$ & $\mathbf{c m}^{\mathbf{3}} / \mathbf{g}$ & \\
\hline USY & 609 & 49 & 0.28 & 0.07 & 0.0596 \\
4AHFS-Y & 598 & 57 & 0.28 & 0.10 & 0.0992 \\
8AHFS-Y & 381 & 92 & 0.18 & 0.17 & 0.1000 \\
12AHFS-Y & 196 & 106 & 0.09 & 0.29 & 0.0831 \\
1NH-Y & 618 & 48 & 0.29 & 0.07 & 0.0581 \\
4NH-Y & 551 & 101 & 0.26 & 0.10 & 0.1119 \\
\hline
\end{tabular}

${ }^{a}$ t-plot micropore area. ${ }^{b} t$-plot external surface. ${ }^{c} t$-plot micropore volume. ${ }^{d}$ Mesopore volume $\left(V_{\text {total }}-V_{\text {micro }}\right)$, Vtotal is total pore volume test at $\mathrm{p} / \mathrm{p} 0=0.99$. ${ }^{\mathrm{e}}$ The hierarchy factor $(\mathrm{HF})=\left(\mathrm{V}_{\text {micro }} / \mathrm{V}_{\text {pore }}\right) \times\left(\mathrm{S}_{\text {meso }} / \mathrm{S}_{\mathrm{BET}}\right)$.

\subsection{Influence of Dealumination and Desilication on the Metal State}

The influence of AHFS or alkaline treatment on the active phase was investigated by hydrogen temperature-programmed reduction $\left(\mathrm{H}_{2}-\mathrm{TPR}\right)$. As shown in Figure 3, the desilicated and dealuminated catalysts showed two principal reduction peaks. The low temperature peak around $500{ }^{\circ} \mathrm{C}$ was very broad and more intense, associated to the reduction of $\mathrm{Mo}^{6+}$ to $\mathrm{Mo}^{4+}$ of polymeric octahedral Mo species and $\mathrm{NiMoO}_{4}{ }^{-}$-like phase weakly bound to the zeolite surface [31,32]. The reduction peak at about $730{ }^{\circ} \mathrm{C}$ was assigned to the reduction of tetrahedrally coordinated Mo species ( $\mathrm{MoO}_{3}$ phase) in the zeolite cavities $[33,34]$. After AHFS treatments, the peak at ca. $500^{\circ} \mathrm{C}$ gradually dissociated into two peaks, respectively assigned to the reduction of polymeric octahedral Mo species and $\mathrm{NiMoO}_{4}{ }^{-}$-like phase. The peak temperature for the polymeric octahedral Mo species shifted to the lower but the peak temperature for $\mathrm{NiMoO}_{4}{ }^{-}$-like phase shifted toward higher. Moreover, the intensity and area of the peak around $500{ }^{\circ} \mathrm{C}$ significantly increased and the peak intensity for $\mathrm{MoO}_{3}$ phase also increase a little as the AHFS concentration increased. These suggested that large amount of Mo species in $\mathrm{NiMoO}_{4}{ }^{-}$and $\mathrm{MoO}_{3}$ phase were produced in the AHFS-treated catalysts. After alkaline treatments, the peak around $500{ }^{\circ} \mathrm{C}$ shifted to a higher temperature, but with a slight increase of the intensity and area as the alkaline concentration increased, suggesting that the proportion of $\mathrm{NiMoO}_{4}{ }^{-}$phase increased with a little increase of the total metal active sites. These results indicated that the AHFS treated catalysts could better improve the dispersion of the active metal to produce more active sites than $\mathrm{NaOH}$-treated catalysts. This was also further proved by CO chemisorption (see Table S1).

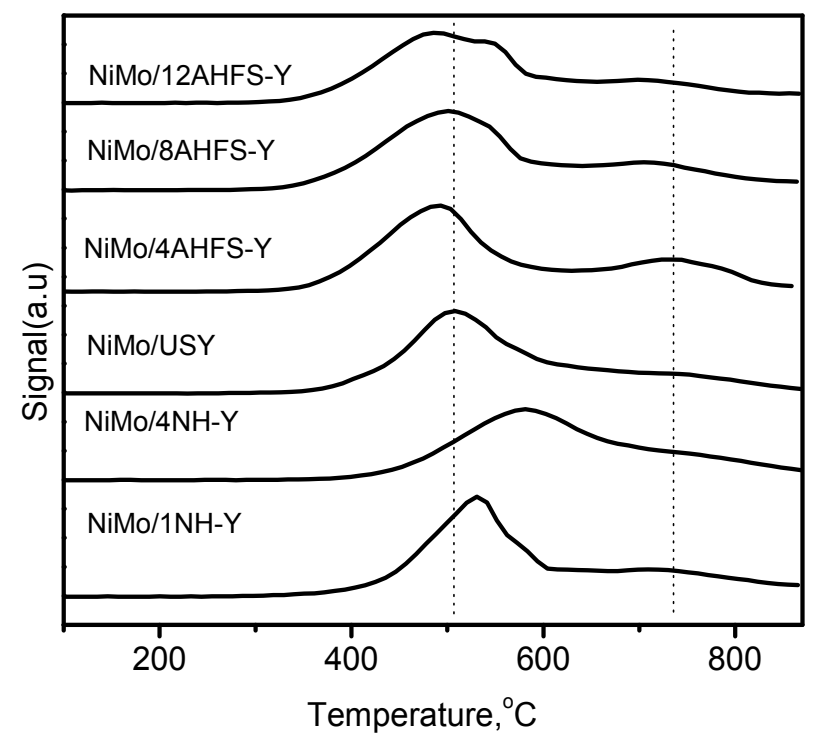

Figure 3. $\mathrm{H}_{2}$-TPR profiles for NiMo catalysts supported on AHFS-treated USY and alkaline-treated USY. 


\subsection{Hydrotreating of Waste Cooking Oil}

The desilicated and dealuminated USY supported sulphide NiMo catalysts showed high activity for the hydroconversion of WCO. The conversions of WCO were all most 100\% for all the experiments. As shown in Figure 4, the yield of organic liquid products $\left(\mathrm{Y}_{\mathrm{OLP}}\right)$ over the $\mathrm{NaOH}$-treated catalysts were almost the same with that of USY, although the amount of strong acid sites of these catalysts was larger than USY. However, the $Y_{\text {OLP }}$ increased with the severity increase of the AHFS treatment. The $82.3 \%$ yield of organic liquid products was obtained on the NiMo/8AHFS-Y catalyst. This indicated that the AHFS treatment could avoid excessive cracking to improve the yield of organic liquid products.

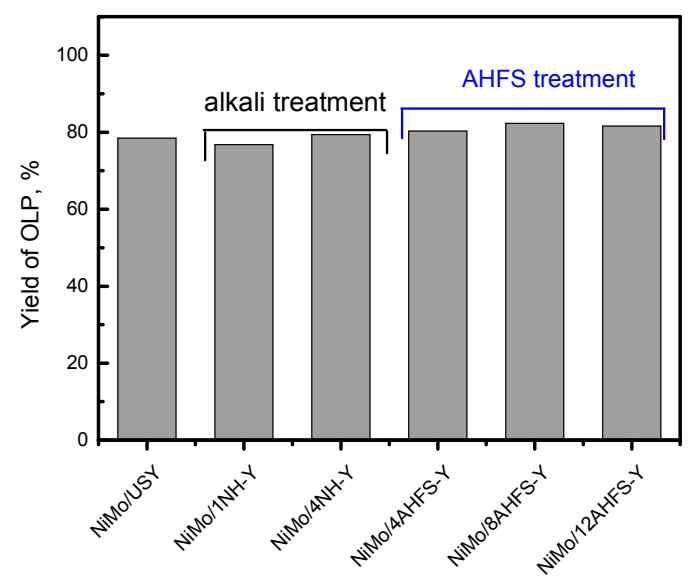

Figure 4. The yield of organic liquid product in the conversion of WCO over different catalysts.

The catalytic conversion of triglycerides to hydrocarbons proceeds through three reaction pathways, hydrodeoxygenation (HDO), decarbonylation (DCO), and decarboxylation $\left(\mathrm{DCO}_{2}\right)$ [9]. The decarbonylation (DCO) and decarboxylation $\left(\mathrm{DCO}_{2}\right)$ produced alkanes with one less carbon than the original fatty acid, but the same carbon atoms by hydrodeoxygenation (HDO). Thus, the molar ratio of $\mathrm{C}_{17} / \mathrm{C}_{18}$ could reflect the tendency of DCOx/HDO reactions. Figure 5 shows the distribution of $\mathrm{H}_{2} \mathrm{O}$, $\mathrm{CO}$, and $\mathrm{CO}_{2}$ produced by different reaction pathways. The observed $\mathrm{CO}_{2} / \mathrm{CO}$ ratios represented the relative rates of $\mathrm{DCO}_{2} / \mathrm{DCO}$ ignoring the water-gas-shift reaction. From Figure $5 \mathrm{~b}$, the yield ratios of $\mathrm{C}_{17} / \mathrm{C}_{18}$ increased for the AHFS treated catalysts and the $\mathrm{CO} /\left(\mathrm{CO}+\mathrm{CO}_{2}\right)$ ratio was down to 0 under high AHFS concentration. This was in agreement with the results of the DCOx selectivity increasing with the increase of $\mathrm{Si} / \mathrm{Al}$ ratio in the $\mathrm{NiMo} / \mathrm{SiO}_{2}-\mathrm{Al}_{2} \mathrm{O}_{3}$ catalysts [35]. In our previous research, we found that the $\mathrm{Mo}^{5+}$ and $\mathrm{Mo}^{6+}$ species mainly contributed to the DCOx reactions, especially the $\mathrm{DCO}_{2}$ reaction, and $\mathrm{Mo}^{4+}$ favoured the $\mathrm{HDO}$ reaction. As shown in Figure 3, there were more Mo species in $\mathrm{NiMoO}^{4-}$ and $\mathrm{MoO}_{3}$ phase produced in the high AHFS-treated catalysts, which were generally accepted to be the active sites for $\mathrm{DCO}_{2}$ reaction [36]. Therefore, the high selectivity of the $\mathrm{DCO}_{2}$ reaction was achieved over the NiMo/8AHFS-Y and NiMo/12AHFS-Y catalysts. As for the $\mathrm{NaOH}$-treated catalysts, the $\mathrm{C}_{17} / \mathrm{C}_{18}$ ratio increased and the $\mathrm{CO} /\left(\mathrm{CO}+\mathrm{CO}_{2}\right)$ ratio gradually decreased, indicating that the selectivity of DCOx, especially the $\mathrm{DCO}_{2}$ reaction, was improved due to the increase of the $\mathrm{NiMoO}^{4-}$ phase content. These results suggested that both the desilication and dealumination could enhance the selectivity of DCOx, especially $\mathrm{DCO}_{2}$ reaction, in the hydroconversion of WCO. The dealumination with AHFS was a more efficient method to enhance the selectivity of $\mathrm{DCO}_{2}$ reaction, and more than $67 \%$ DCOx selectivity $\left(100 \%\right.$ in $\left.\mathrm{DCO}_{2}\right)$ reactions were achieved over high AHFS-treated catalysts. 

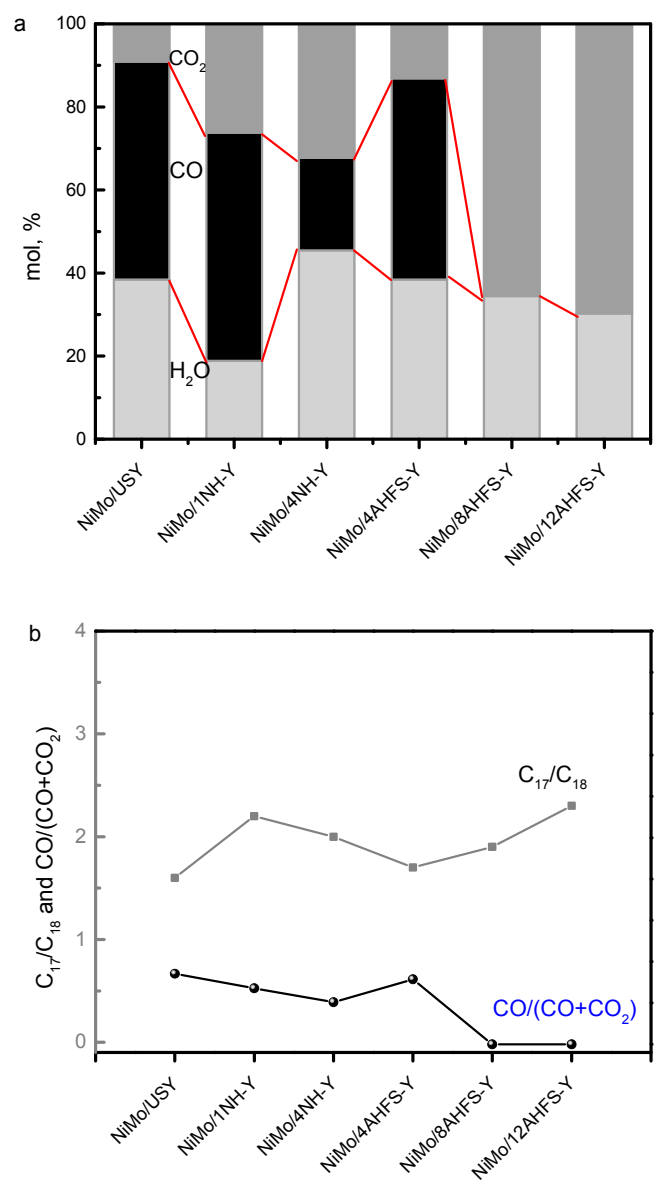

Figure 5. (a) Distribution of $\mathrm{H}_{2} \mathrm{O}, \mathrm{CO}, \mathrm{CO}_{2}$ products and (b) the variation of $\mathrm{C}_{17} / \mathrm{C}_{18}$ and $\mathrm{CO} /(\mathrm{CO}+$ $\mathrm{CO}_{2}$ ) in the conversion of WCO over different catalysts.

The products distributions were further analysed and summarized in Figure 6a. As for the AHFS-treated catalysts, it could be found that the selectivity of the gasoline-ranged hydrocarbons $\left(\mathrm{C}_{4}-\mathrm{C}_{8}\right)$ decreased significantly compared with the NiMo/USY catalyst (from $76.6 \%$ to $52 \%$ for NiMo/4AHFS-Y) and further decreased to 30\% (NiMo/8AHFS-Y) with the increase of the AHFS concentration. Meanwhile, the selectivity of jet fuel $\left(\mathrm{C}_{9}-\mathrm{C}_{15}\right.$ hydrocarbons) dramatically increased from $9.3 \%$ to $42.3 \%$ (NiMo/8AHFS-Y). The selectivity of diesel fraction $\left(\mathrm{C}_{16}-\mathrm{C}_{18}\right.$ hydrocarbons) also increased significantly (14.4\% to $27.7 \%$ ). This indicated that the cracking activity over the AHFS-treated catalysts decreased. It was possible that the deep cracking reaction was restrained by the decrease of the acid sites density, especially the Brønsted sited density. It should be noted that the NiMo/8AHFS-Y catalyst showed the suitable activity for selective cracking although the acid site density was very low. This might be attributed to the better acid distribution and mass transfer by the resulted hierarchical structure. While after low-concentration $\mathrm{NaOH}$ treatment, the NiMo/1NH-Y catalyst showed high selectivity of $\mathrm{C}_{4}-\mathrm{C}_{8}$ hydrocarbons $(86.4 \%)$ due to the higher density of acid sites. However, after high concentration $\mathrm{NaOH}$ treatment, it was interested that although the acid sites density of NiMo/4NH-Y catalyst was much higher than NiMo/USY catalyst, the selectivity to the jet fuel fraction significantly increased to $29.7 \%$ with a relative low selectivity of $\mathrm{C}_{4}-\mathrm{C}_{8}$ hydrocarbons $(47.3 \%)$. These results suggested that the selective cracking mainly depended on the location of acid sites, not the acid site density. The acid sites in the mesopore channel had better activity for selective hydroconversion of WCO than in the micropore and on the surface, and dealumination could produce a better hierarchical structure and acid distribution than desilicaton. 

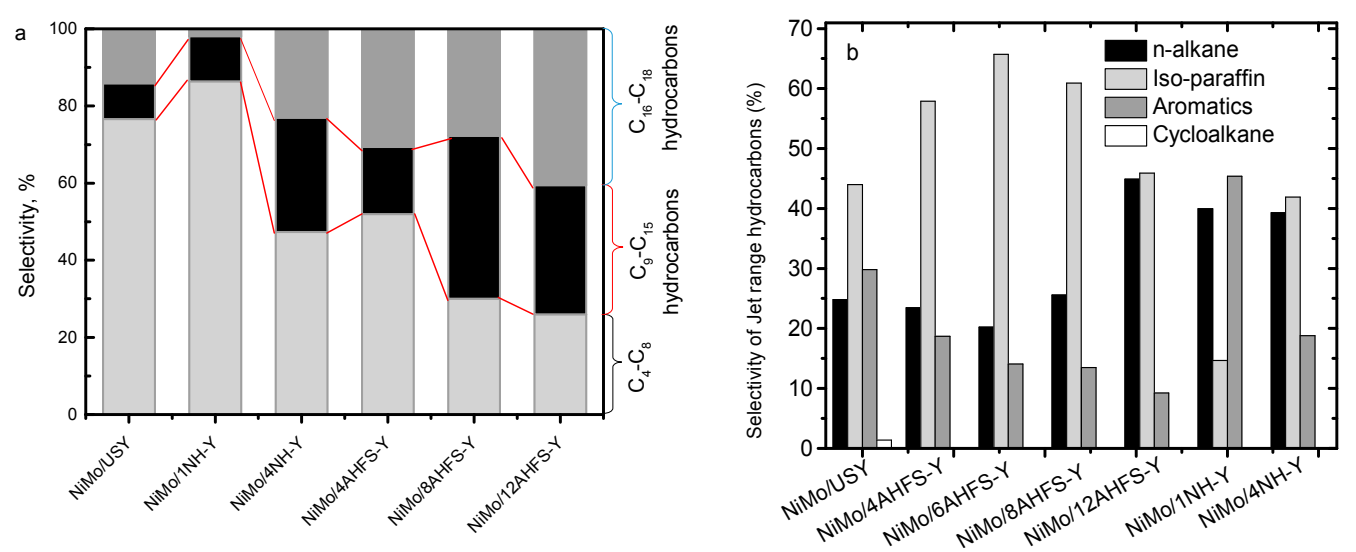

Figure 6. (a) The products distribution and (b) selectivity of various jet range hydrocarbon in the conversion of WCO over different catalysts.

Figure $6 \mathrm{~b}$ shows the product distribution of $\mathrm{C}_{9-15}$ hydrocarbons over different catalysts. After mild AHFS treatment, the $i s o-/ n$-paraffins ratio $(i / n)$ increased. The $i / n$ ratios were $2.38,2.47$, and 3.25 corresponding to the ratio of the weak and strong acidity of $0.29,0.47$, and 0.56 (Table 2). After $\mathrm{NaOH}$ treatment, the $i / n$ ratio decreased because of the stronger Brønsted acidity. Aromatic compounds were also produced besides paraffins. From Figure $6 \mathrm{~b}$ the selectivity of jet-range aromatics (based on boiling point from $\mathrm{C}_{9}$ to $\mathrm{C}_{15}$ ) over the NiMo/AHFS-Y catalysts decreased with the increase of the AHFS concentration. This result indicated that the aromatization reaction of the cracking products was inhibited after AHFS treatment because of the decrease of the Brønsted and Lewis acidity. Recently, we found that the B/L ratio also played an important role in aromatization of olefins [36]. After AHFS treatment, the similar $\mathrm{B} / \mathrm{L}$ ratio was obtained but the amount of these acid sites decreased significantly. Comparing to the NiMo/USY catalyst, the selectivity for jet-range aromatics over the NiMo/8AHFS-Y catalyst decreased about only by half ( $29.8 \%$ to $13.5 \%$ ) although the amount of Brønsted and Lewis acid for the NiMo/USY catalyst was about 10 times as high as that for the NiMo/8AHFS-Y catalyst. Moreover the trimethylbenzene and methyl ethylbenzene in the aromatics increased because the proportion increase of stronger acid sites favoured the dealkylation of the higher aromatics with the increase of the AHFS concentration [37]. The selectivity of jet range aromatic hydrocarbons over NiMo/1NH-Y increased because of the density increase of strong Brønsted and Lewis sites. However, the selectivity of aromatic hydrocarbons over $\mathrm{NiMo} / 4 \mathrm{NH}-\mathrm{Y}$ decreased, probably due to the mismatching the $\mathrm{B} / \mathrm{L}$ ratio and the enhancement of mass transfer by the mesopores. These results further indicated the importance of the $\mathrm{B} / \mathrm{L}$ ratio for aromatization in hydroconversion of triglycerides.

\subsection{Stability of Catalysts}

The production of coke was the result of the formation of heavy compounds, which may cover certain acid sites and cause a hindrance to diffusion or block the channels of the catalyst and change the cracking activity [38]. The amount of coke was determined by TG in air. Figure 7 shows the observed mass losses for used catalysts after reaction for $7 \mathrm{~h}$. As shown in Figure $7 \mathrm{~b}$, four stages of the mass loss from $30{ }^{\circ} \mathrm{C}$ to $230{ }^{\circ} \mathrm{C}, 230{ }^{\circ} \mathrm{C}$ to $330{ }^{\circ} \mathrm{C}, 330{ }^{\circ} \mathrm{C}$ to $520^{\circ} \mathrm{C}$, and $520^{\circ} \mathrm{C}$ to $700{ }^{\circ} \mathrm{C}$ were observed which corresponded to the loss of adsorbed water, the formed soft coke, hard coke, and graphite, respectively [39]. The mass loss from $230{ }^{\circ} \mathrm{C}$ to $700{ }^{\circ} \mathrm{C}$ for used NoMo/USY, NiMo/4AHFS-Y, NiMo/6AHFS-Y, NiMo/8AHFS-Y, NiMo/1NH-Y, and NiMo/4NH-Y catalysts were 22.78\%, 22.52\%, $15.62 \%, 7.91 \%, 16.23 \%$, and $15.34 \%$, respectively. The total coke of used NiMo/AHFS-Y catalysts decreased with the increase in AHFS treatment severity. There were two likely reasons: Firstly, the number of acid sites, especially the strong acid sites, were mainly responsible for the coke deposition [40]. From Table 2, the AHFS-Y zeolites had a drastically lower acid amount than the corresponding USY zeolites and the acid amount decreased with the increase in AHFS treatment 
severity. Secondly, the macromolecules would form in the free cavities of USY, and hard coke essentially located in the zeolite cavities and was difficult to diffuse out from the channel. From Table 3, the volume and the size of mesopores of AHFS treated USY increased, which would reduce the chance of the coke formation [41]. Although the number of strong acid sites increased for the alkaline treated USY, the volume of mesopores also increased, which reduced the coke.

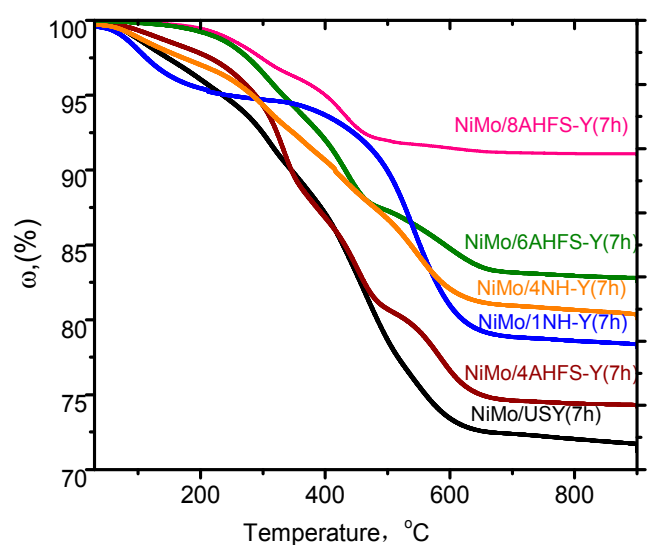

(a)

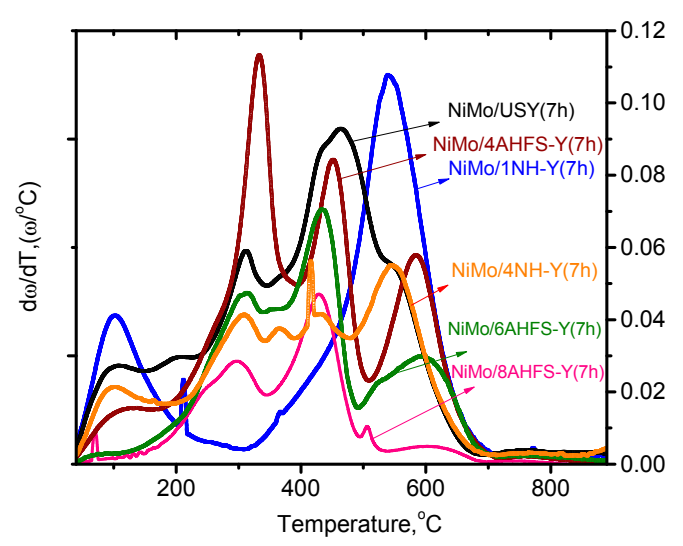

(b)

Figure 7. (a) TG and (b) DTG profiles for used NiMo/USY, NiMo/AHFS-Y, and NiMo/NH-Y catalysts.

\section{Experimental}

\subsection{Materials}

Commercial USY zeolite was purchased from Nankai University Catalyst Co. (Tianjin, China). $\left(\mathrm{NH}_{4}\right)_{6} \mathrm{Mo}_{7} \mathrm{O}_{24}\left(\geq 99\right.$ wt \%, J\&K Chemical Ltd., Beijing, China), $\mathrm{Ni}\left(\mathrm{NO}_{3}\right)_{2}(\geq 98$ wt \%, Alfa Aesar, Shanghai, China), cyclohexane, ammonium nitrate $\left(\mathrm{NH}_{4} \mathrm{NO}_{3}\right)$, ammonium hexafluorosilicate $\left(\mathrm{NH}_{4}\right)_{2} \mathrm{SiF}_{6}(\geq 98 \mathrm{wt} \%)$, and sodium hydroxide $(\mathrm{NaOH})$ were purchased fromTianjin Guangfu Chemical Industry (Tianjin, China). The waste cooking oil was supplied by Tianjin Bihai Environmental Protection Ltd., Co., (Tianjin, China), which consisted of a mixture of used cooking oil mainly collected from local restaurants after being used for frying. WCO was filtered by a regular sieve to remove the remaining food particles before used as feedstock. The main physical and chemical properties of WCO are listed in Table 4.

Table 4. Physical and chemical properties of waste cooking oil.

\begin{tabular}{cc}
\hline Property & Waste Cooking Oil \\
\hline Palimitic acid $\left(\mathrm{C}_{16: 0}, \mathrm{wt} \%\right)$ & 25.02 \\
Linoleic acid $\left(\mathrm{C}_{18: 2}, \mathrm{wt} \%\right)$ & 28.85 \\
Oleic acid $\left(\mathrm{C}_{18: 1}, \mathrm{wt} \%\right)$ & 39.69 \\
Stearic acid $\left(\mathrm{C}_{18: 0}, \mathrm{wt} \%\right)$ & 6.27 \\
Other acid $(\mathrm{wt} \%)$ & 0.17 \\
Acid value $\left(\mathrm{mg} \mathrm{KOH}^{-1}\right)$ & 65.47 \\
\hline
\end{tabular}

\subsection{Catalyst Preparation}

\subsubsection{Alkaline Treatment}

In a typical run, USY powders were added into $\mathrm{NaOH}$ aqueous solution with different concentrations ( $1 \mathrm{wt} \%, 4 \mathrm{wt} \%$ ). The mixture was heated to $363 \mathrm{~K}$ and stirred for $1 \mathrm{~h}$ in an oil bath. The slurry was filtered and washed with hot deionized water until neutral. Then, the obtained catalyst was dried at $393 \mathrm{~K}$ for $12 \mathrm{~h}$ and was converted into the H-type by three ion-exchanges (10 $\mathrm{g}$ sample in $100 \mathrm{~mL}$ 
of $0.5 \mathrm{M} \mathrm{NH}_{4} \mathrm{NO}_{3}$ ). Before the third exchange, the sample was calcined at $823 \mathrm{~K}$ for $5 \mathrm{~h}$ for the $\mathrm{Na}^{+}$ immigration from the $\beta$-cage to the supercage. Finally, the resultant samples were dried at $393 \mathrm{~K}$ overnight and calcined at $823 \mathrm{~K}$ for $5 \mathrm{~h}$. The samples were denoted as $1 \mathrm{NH}-\mathrm{Y}$ and $4 \mathrm{NH}-\mathrm{Y}$, respectively.

\subsubsection{AHFS Treatment}

The dealumination of USY was carried out in AHFS solutions according to the method in [25]. Ten grams of USY was suspended in $100 \mathrm{~g}$ distilled water and heated to $338 \mathrm{~K}$, then an appropriate amount of AHFS with varying concentrations $(4,8$, and $12 \mathrm{wt} \%)$ was added dropwise. The slurry was stirred at $338 \mathrm{~K}$ for $3 \mathrm{~h}$. Then the zeolites were recovered by filtration and washed using deionized water to neutral. Samples were dried at $393 \mathrm{~K}$ for $12 \mathrm{~h}$ and calcined at $823 \mathrm{~K}$ for $5 \mathrm{~h}$. The obtained samples were denoted as 4AHFS-Y, 8AHFS-Y, and 12AHFS-Y respectively.

\subsubsection{Preparation of NiMo/Hierarchical USY}

Ni $(4.0 \mathrm{wt} \%)$ and Mo (12 wt \%) were loaded on hierarchical USY by incipient wetness co-impregnation with the $\left(\mathrm{NH}_{4}\right)_{6} \mathrm{Mo}_{7} \mathrm{O}_{24}$ and $\mathrm{Ni}\left(\mathrm{NO}_{3}\right)_{2}$ aqueous solution. After impregnation, the samples were kept overnight at room temperature, dried at $393 \mathrm{~K}$ for $12 \mathrm{~h}$, and finally calcined at $823 \mathrm{~K}$ for $4 \mathrm{~h}$.

\subsection{Characterizations}

XRD measurements were performed by using a D/MAX-2500 X-ray diffractometer with $(\mathrm{Cu}-\mathrm{K} \alpha)$ radiation at $40 \mathrm{kV}$ and $140 \mathrm{~mA}$. The patterns were recorded in the $2 \theta$ range from $5^{\circ}$ to $60^{\circ}$ at a scanning rate of $2^{\circ} / \mathrm{min}$. The framework $\mathrm{Si} / \mathrm{Al}$ ratios of USY zeolites were estimated by Equation (1) [42]. The relative crystallinity was calculated by comparing the total peak intensities of (311), (331), (440), (533), (642), and (555) reflections between the treated samples and USY sample. The bulk Si/Al ratio of the zeolites was determined by an S4 PIONEER X-ray fluorescence (XRF) spectrometer.

$$
\text { Framework Si } / \mathrm{Al} \text { ratio }=(25.858-\alpha) /(\alpha-24.191)
$$

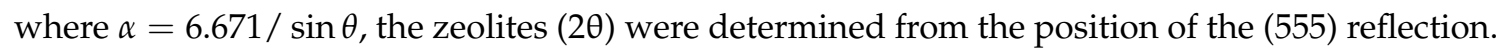

Ammonia temperature programmed desorption $\left(\mathrm{NH}_{3}-\mathrm{TPD}\right)$ was conducted on a chemisorption physisorption analyser (AMI-300, Altamira Instruments, Pittsburgh, PA., USA) equipped with a thermal conductivity detector (TCD). For the $\mathrm{NH}_{3}$-TPD analysis, the samples were pretreated at $773 \mathrm{~K}$ in $\mathrm{He}$ for $1 \mathrm{~h}$. After the samples cooled to $353 \mathrm{~K}, \mathrm{NH}_{3}$ adsorption was carried out by $\mathrm{NH}_{3}$ in $\mathrm{He}$ at $393 \mathrm{~K}$ for $30 \mathrm{~min}$. The $\mathrm{NH}_{3}$-TPD profile was recorded from $393 \mathrm{~K}$ to $973 \mathrm{~K}$ after removing weakly adsorbed $\mathrm{NH}_{3}$ by purging with $\mathrm{He}$ at $393 \mathrm{~K}$ for $2 \mathrm{~h}$.

Py-FTIR measurement were carried out on a Bruker Vertex 70 FTIR spectrometer with a resolution of $4 \mathrm{~cm}^{-1} .10 \mathrm{mg}$ of the samples was pressed into a 13-mm-diameter self-supporting wafer and then was placed into the IR cell with $\mathrm{CaF}_{2}$ windows. All samples were pre-treated under vacuum at $673 \mathrm{~K}$ for $1 \mathrm{~h}$ before Py-FTIR measurement. The background was recorded prior to adsorption experiments after the samples were cooled to $200{ }^{\circ} \mathrm{C}$. Pyridine was injected into the cell and then was left in flowing $\mathrm{N}_{2}$ for 30 min to allow the physisorbed pyridine to be desorbed. Spectra were recorded in the range of 1300 to $4000 \mathrm{~cm}^{-1}$. The specific surface areas and pore volumes and pore size distribution of the samples were determined by $\mathrm{N}_{2}$ adsorption-desorption isotherms on a Micromeritics ASAP-2020 apparatus. Before analysis, all samples were outgassed at $573 \mathrm{~K}$ for $4 \mathrm{~h}$.

$\mathrm{H}_{2}$-TPR experiments were conducted to determine the metal-support interaction and the metal dispersion. Before measurement, the samples were pretreated at $723 \mathrm{~K}$ in $\mathrm{He}$ for $1 \mathrm{~h}$ and cooled to room temperature. The reduction step was performed with a mixture of $10 \% \mathrm{H}_{2}$ in $\mathrm{He}$, with a heating rate of $10 \mathrm{~K} / \mathrm{min}$, up to $1173 \mathrm{~K}$. In the $\mathrm{CO}$ chemisorption experiments, the sample $(100 \mathrm{mg})$ was pretreated in helium at $393 \mathrm{~K}$ for $1 \mathrm{~h}$. Subsequently the sample was reduced in $\mathrm{H}_{2}$ flow $\left(50 \mathrm{~cm}^{3} / \mathrm{min}\right)$ at $723 \mathrm{~K}$ for $2 \mathrm{~h}$ and then evacuated at $723 \mathrm{~K}$ for $2 \mathrm{~h}$. Finally the sample was cooled to $313 \mathrm{~K}$ in vacuum. 
Afterward the CO adsorption isotherm was recorded at $313 \mathrm{~K}$ based on the amount of adsorbed $\mathrm{CO}$ at different pressures.

\subsection{Hydrotreating of Waste Cooking Oil}

The hydroconversion of WCO was carried out in a fixed-bed flow reactor $(1.2 \mathrm{~cm}$ I.D. and $45 \mathrm{~cm}$ in length). The reaction temperature was monitored with a thermocouple in the catalyst bed. Eight grams of the catalyst were diluted by $\mathrm{SiC}$ to obtain sufficient catalyst-bed length and was loaded into the steel reactor. WCO $(20 \mathrm{wt} \%)$ in cyclohexane was used as the feedstock and supplied at a flow of $0.8 \mathrm{~mL} / \mathrm{min}$. The reactions were conducted at $380{ }^{\circ} \mathrm{C}$ under $3 \mathrm{MPa}$ with $\mathrm{H}_{2} /$ Oil ratio $(\mathrm{mL} / \mathrm{mL})$ was 500 . The catalysts were presulfided in situ at $320^{\circ} \mathrm{C}$ and $3.0 \mathrm{MPa}$ for $4 \mathrm{~h}$ using $3.0 \mathrm{wt} \% \mathrm{CS}_{2}$ in cyclohexane.

After the reaction reached stable (at least $5 \mathrm{~h}$ ), the products were collected and were separated into gaseous products and the liquid products by a separator. The gaseous products were analysed by an Agilent Micro 3000 gas chromatograph equipped with three columns (molecular sieve, plot U, and alumina) and TCD detectors. The liquid fraction was separated into water and organic liquid products (OLPs). The water was weighted. The organic liquid products were qualitatively determined with an Agilent $6890 \mathrm{~N}$ gas chromatography $/ 5975 \mathrm{~N}$ mass spectrometry (GC/MS). The hydrocarbons were quantitatively determined with a gas chromatographs (Bruker 456 GC, Bruker, San Francisco, CA, USA), equipped with a flame ionization detector (FID) and a commercially column (ZB-5 HT, $60 \mathrm{~m} \times 0.25 \mathrm{~mm} \times 0.25 \mu \mathrm{m})$. The conversion and selectivity were calculated by Equations (2)-(4):

$$
\begin{gathered}
\text { Conversion }=100 \% \times\left(\text { Feed }_{\mathrm{G}}-\text { Product }_{\mathrm{G}}\right) / \text { Feed }_{\mathrm{G}} \\
\text { Selectivity }_{(\mathrm{CxHy})}=(\mathrm{CH})_{\text {nproducts }} / \Sigma(\mathrm{CH})_{\text {nproducts }} \\
\text { Selectivity of aromatics }=\Sigma(\mathrm{CH})_{\text {aromatics }} / \Sigma(\mathrm{CH})_{\text {nproducts }}
\end{gathered}
$$

\section{Conclusions}

The hydrotreatment of waste cooking oil into a bio-jet fuel fraction was enhanced over the desilicated and dealuminated USY-supported sulfided NiMo catalysts. After desilicaton and dealumination, the mesopores with different inner surface structure were formed. The desilicated USY zeolite formed a high density of Brønsted acid sites. However, the dealuminated catalysts produced a low-acidity distribution and much larger mesopores than the dealuminated catalyst. The Brønsted acidity decreased in the AHFS treatment. A large amount of Mo species in $\mathrm{NiMoO}_{4}{ }^{-}$and $\mathrm{MoO}_{3}$ phases were produced in the AHFS-treated catalysts, while much more high-valence-state Mo species in the $\mathrm{NiMoO}_{4}{ }^{-}$phase was formed over the $\mathrm{NaOH}$-treated catalysts. Therefore, the catalysts modified by desilication and dealumination could enhance the selectivity of DCOx reactions. The AHFS-treated catalysts showed higher catalytic activity, prone to $\mathrm{DCO}_{2}$ selectivity and better selective cracking for jet fuel.

Supplementary Materials: The following are available online at www.mdpi.com/2073-4344/7/10/281/s1, Figure S1: $\mathrm{NH}_{3}$-TPD profiles of AHFS and alkaline treated USY; Figure S2: $\mathrm{NH}_{3}$-TPD profiles of AHFS and alkaline treated USY; Figure S3: (a) $\mathrm{N}_{2}$ adsorption-desorption isotherms and (b) the mesopore size distribution for the AHFS treated and/or alkaline- treated USY; Table S1: The adsorbed CO determined by TPD characterization; Table S2: Crystal structure parameters of modified USY; Table S3: Acidity properties of samples ( $\mu \mathrm{mol} / \mathrm{g}$ ); Table S4: The surface area and pore volume data of all the Y type zeolites involved; Table S5: Yield and selectivity of different hydrocabons in the hydrotreatmentwaste cookingwaste cooking oil.

Acknowledgments: This work is financially supported by the National Natural Science Foundation of China (21476169, 21476168).

Author Contributions: All authors conceived and designed the experiments; Z.W. and H.C. performed the experiments; W.Q. and X.W. analysed the data; and Z.W. wrote the paper.

Conflicts of Interest: The authors declare no conflict of interest. 


\section{References}

1. Rye, L.; Blakey, S.; Wilson, C.W. Sustainability of supply or the planet: A review of potential drop-in alternative aviation fuels. Energy Environ. Sci. 2010, 3, 17-27. [CrossRef]

2. Kon, K.; Onodera, W.; Shimizu, K.I. Selective hydrogenation of levulinic acid to valeric acid and valeric biofuels by a Pt/HMFI catalyst. Catal. Sci. Technol. 2014, 4, 3227-3234. [CrossRef]

3. Horacek, J.; Homola, F.; Kubickova, I. Lignin to liquids over sulfided catalysts. Catal. Today 2012, 179, 191-198. [CrossRef]

4. Stumborg, M.; Wong, A.; Hogan, E. Hydroprocessed vegetable oils for diesel fuel improvement. Bioresour. Technol. 1996, 56, 13-18. [CrossRef]

5. Sandor, K.; Tamas, K.; Artur, T. Fuel production by hydrotreating of triglycerides on $\mathrm{NiMo} / \mathrm{Al}_{2} \mathrm{O}_{3} / \mathrm{F}$ catalyst. Chem. Eng. J. 2011, 176, 237-243.

6. Satyarthi, J.K.; Chiranjeevi, T.; Gokak, D.T.; Viswanathan, P.S. An overview of catalytic conversion of vegetable oils/fats into middle distillates. Catal. Sci. Technol. 2013, 3, 70-80. [CrossRef]

7. Perego, C.; Ricci, M. Diesel fuel from biomass. Catal. Sci. Technol. 2012, 2, 1776-1786. [CrossRef]

8. Yang, Y.; Wang, Q.; Zhang, X.; Wang, L.; Li, G. Hydrotreating of C18 fatty acids to hydrocarbons on sulphided $\mathrm{NiW} / \mathrm{SiO}_{2}-\mathrm{Al}_{2} \mathrm{O}_{3}$. Fuel Process. Technol. 2013, 116, 165-174. [CrossRef]

9. Bezergianni, S.; Kalogianni, A. Hydrocracking of used cooking oil for biofuels production. Bioresour. Technol. 2009, 100, 3927-3932. [CrossRef] [PubMed]

10. Rogelio, S.B.; Fernando, T.Z.; Felipe, J.H.L. Hydroconversion of Triglycerides into Green Liquid Fuels. In Hydrogenation; Karamé, I., Ed.; InTech: Rijeka, Croatia, 2012; pp. 188-216.

11. Honeywell UOP, Honeywell Green Jet Fuel. Available online: http://www.uop.com/processing-solutions / renewables/green-jet-fuel/\#uop-renewable-jet-fuel-process (accessed on 20 October 2016).

12. Verma, D.; Kumar, R.; Rana, B.S.; Sinha, A.K. Aviation fuel production from lipids by a single-step route using hierarchical mesoporous zeolites. Energy Environ. Sci. 2011, 4, 1667-1671. [CrossRef]

13. Verma, D.; Rana, B.S.; Kumar, R.; Sibi, M.G.; Sinha, A.K. Diesel and aviation kerosene with desired aromatics from hydroprocessing of jatropha oil over hydrogenation catalysts supported on hierarchical mesoporous SAPO-11. Appl. Catal. A Gen. 2015, 490, 108-116. [CrossRef]

14. Rocha Filho, G.N.; Brodzki, D.; Djega-Mariadassou, G. Formation of alkanes, alkylcycloalkanes and alkylbenzenes during the catalytic hydrocracking of vegetable oils. Fuel 1993, 72, 543-549. [CrossRef]

15. Morais, S.; Mata, T.M.; Martins, A.A.; Pinto, G.A.; Costa, C.A.V. Simulation and life cycle assessment of process design alternatives for biodiesel production from waste vegetable oils. J. Clean. Prod. 2010, 18, 1251-1259. [CrossRef]

16. Chiaramonti, D.; Prussi, M.; Buffi, M.; Tacconi, D. Sustainable bio kerosene: Process routes and industrial demonstration activities in aviation biofuels. Appl. Energy 2014, 136, 767-774. [CrossRef]

17. Talebian-Ki akalaieha, A.; Amina, N.A.S.; Mazaheria, H. A review on novel processes of biodiesel production from waste cooking oil. Appl. Energy 2013, 104, 683-710. [CrossRef]

18. Yaakob, Z.; Mohammad, M.; Alherbawi, M.; Alam, Z.; Sopian, K. Overview of the production of biodiesel from Waste cooking oil. Renew. Sustain. Energy Rev. 2013, 18, 184-193. [CrossRef]

19. Li, T.; Cheng, J.; Huang, R.; Zhou, J.; Cen, K. Conversion of waste cooking oil to jet biofuel with nickel-based mesoporous zeolite Y catalyst. Bioresour. Technol. 2015, 197, 289-294. [CrossRef] [PubMed]

20. Liu, S.; Zhu, Q.; Guan, Q.; He, L.; Li, W. Bio-aviation fuel production from hydroprocessing castor oil promoted by the nickel-based bifunctional catalyst. Bioresour. Technol. 2015, 183, 93-100. [CrossRef] [PubMed]

21. Garralon, G.; Fornes, V.; Corma, A. Faujasites dealuminated with ammonium hexafluorosilicate: Variables affecting the method of preparation. Zeolites 1988, 8, 268-272. [CrossRef]

22. Silaghi, M.C.; Chizallet, C.; Raybaud, P. Challenges on molecular aspects of dealumination and desilication of zeolites. Microporous Mesoporous Mater. 2014, 191, 82-96. [CrossRef]

23. Verboekend, D.; Nuttens, N.; Locus, R.; Van Aelst, J.; Verolme, P.; Groen, J.C.; Pérez-Ramírez, J.; Selsa, B.F. Synthesis, characterisation, and catalytic evaluation of hierarchical faujasite zeolites: Milestones, challenges, and future directions. Chem. Soc. Rev. 2016, 45, 3331-3352. [CrossRef] [PubMed] 
24. Huang, S.; Chen, P.Z.; Yan, B.; Wang, S.; Shen, Y.; Ma, X. Modification of Y Zeolite with Alkaline Treatment: Textural Properties and Catalytic Activity for Diethyl Carbonate Synthesis. Ind. Eng. Chem. Res. 2013, 52, 6349-6356. [CrossRef]

25. Qin, Z.; Shen, B.; Gao, X.; Lin, F.; Wang, B.; Xu, C. Mesoporous Y zeolite with homogeneous aluminum distribution obtained by sequential desilication-dealumination and its performance in the catalytic cracking of cumene and 1,3,5-triisopropylbenzen. J. Catal. 2011, 278, 266-275. [CrossRef]

26. Qin, Z.; Shen, B.; Yu, Z.W.; Deng, F.; Zhao, L.; Zhou, S.; Yuan, D.; Gao, X.; Wang, B.; Zhao, H.; et al. A defect-based strategy for the preparation of mesoporous zeolite $\mathrm{Y}$ for high-performance catalytic cracking. J. Catal. 2013, 298, 102-111. [CrossRef]

27. Donk, S.; Janssen, A.H.; Bitter, J.H. Generation, Characterization, and Impact of Mesopores in Zeolite Catalysts. Catal. Rev. 2003, 45, 297-319. [CrossRef]

28. Corma, A.; Fornes, V.; Rey, F. Extraction of extra-framework aluminium in ultrastable Y zeolites by $\left(\mathrm{NH}_{4}\right)_{2} \mathrm{SiF}_{6}$ treatments: I. Physicochemical Characterization. Appl. Catal. 1990, 37, 267-274. [CrossRef]

29. Xu, B.; Bordiga, S.; Prins, R.; Van Bokhoven, J.A. Effect of framework Si/Al ratio and extra-framework aluminum on the catalytic activity of Y zeolite. Appl. Catal. A Gen. 2007, 333, 245-253. [CrossRef]

30. Peng, X.; Zhang, Y.Z.; Zheng, L.B. Isomorphous subsitution of Faujusite with $\left(\mathrm{NH}_{4}\right)_{2} \mathrm{SiF}_{6}$ : Reaction conditions and properties of products. J. Catal. 1991, 13, 32-37.

31. Peng, X.; Zhang, Y.; Zheng, L.B. Isomorphous subsitution of Faujusite with $\left(\mathrm{NH}_{4}\right)_{2} \mathrm{SiF}_{6}$ : Reaction mechanism. J. Catal. 1993, 14, 300-306.

32. Cordero, R.L.; Agudo, A.L. Effect of water extraction on the surface properties of $\mathrm{Mo} / \mathrm{Al}_{2} \mathrm{O}_{3}$ and $\mathrm{NiMo} / \mathrm{Al}_{2} \mathrm{O}_{3}$ hydrotreating catalysts. Appl. Catal. A Gen. 2000, 202, 23-35. [CrossRef]

33. Cordero, R.L.; Llambias, F.J.G.; Agudo, A.L. Temperature-programmed reduction and zeta potential studies of the structure of $\mathrm{MoO}_{3} / \mathrm{Al}_{2} \mathrm{O}_{3}$ and $\mathrm{MoO}_{3} / \mathrm{SiO}_{2}$ catalysts effect of the impregnation $\mathrm{pH}$ and molybdenum loading. Appl. Catal. 1991, 74, 125-136. [CrossRef]

34. Solis, D.; Agudo, A.L.; Ramírez, J.; Klimova, T. Hydrodesulfurization of hindered dibenzothiophenes on bifunctional NiMo catalysts supported on zeolite-alumina composites. Catal. Today 2006, 116, 469-477. [CrossRef]

35. Gong, S.; Shinozaki, A.; Qian, E.W. Role of Support in Hydrotreatment of Jatropha Oil over Sulfided NiMo Catalysts. Ind. Eng. Chem. Res. 2012, 51, 13953-13960. [CrossRef]

36. Chen, H.; Wang, Q.; Zhang, X.; Wang, L. Quantitative conversion of triglycerides to hydrocarbons over hierarchical ZSM-5 catalyst. Appl. Catal. B Environ. 2015, 166-167, 327-334. [CrossRef]

37. Adjaye, J.D.; Katikaneni, S.P.R.; Bakhshi, N.N. Catalytic conversion of a biofuel to hydrocarbons: Effect of mixtures of HZSM-5 and silica-alumina catalysts on product distribution. Fuel Process. Technol. 1996, 48, 115-143. [CrossRef]

38. Liu, X.J.; Guan, L.L.; Fu, X.N.; Zhao, Y.; Wu, J.D.; Xu, N. Nanocone arrays synthesized by plasma-assisted reaction deposition. Nanoscale Res. Lett. 2014, 9, 550. [CrossRef] [PubMed]

39. Li, Y.; Zhang, C.S.; Liu, Y.G.; Hou, X.; Zhang, R.; Tang, X. Coke Deposition on Ni/HZSM-5 in Bio-oil Hydrodeoxygenation Processing. Energy Fuels. 2015, 29, 1722-1728. [CrossRef]

40. Silva, A.O.S.; Souza, M.J.B.; Aquino, J.M.F.B.; Fernandes, V.J., Jr.; Araujo, A.S. Acid properties of the HZSM-12 zeolite with different $\mathrm{Si} / \mathrm{Al}$ ratio by thermo-programmed desorption. J. Therm. Anal. Calorim. 2004, 76, 783-791. [CrossRef]

41. Liu, J.X.; Cai, G.; Yang, L.X.; Gao, X.-Y.; Ji, P.; Chen, G.-Q. The coking behaviour of zeolife catalysts during the conversion of methanol to lower olefins. J. Catal. 1985, 6, 238-244.

42. Breck, D.W.; Flanigen, E.M. Molecular Sieves; Society of Chemical: London, UK, 1968.

(C) 2017 by the authors. Licensee MDPI, Basel, Switzerland. This article is an open access article distributed under the terms and conditions of the Creative Commons Attribution (CC BY) license (http:/ / creativecommons.org/licenses/by/4.0/). 